\title{
Number of tooth loss in smokers and non-smokers in Monmata Lhoong Village, Aceh Besar District, Indonesia
}

\author{
${\text { Liana Rahmayani }{ }^{*} \text {, Dewi Saputri }{ }^{2}, \text { Chairunas }^{3}, \text { Syahrial }^{1}, \text { Maisura }}^{1}$ \\ 1Department of Prosthodontics, Faculty of Dentistry Syiah Kuala University, Indonesia \\ ${ }^{2}$ Department of Periodontics, Faculty of Dentistry Syiah Kuala University, Indonesia \\ ${ }^{3}$ Department of Dental Surgery, Faculty of Dentistry Syiah Kuala University, Indonesia
}

\begin{abstract}
Introduction: Tooth loss is a condition that occurs in most of the world's population. The most common causes of tooth loss are caries and periodontal disease. Periodontal disease can usually increase or getting worse by bad habits such as smoking. Smoking accelerates the course of periodontal disease and decreases salivary secretion, whereby increased the risk of caries incidence. Some components of the cigarette's smoke that can accelerate the course of periodontal diseases are nicotine and tar. The purpose of this study was to determine the difference in the number of tooth loss in smokers and nonsmokers. Methods: This study was a cross-sectional study. The sampling method was by the tables of Isaac and Michael, involving 78 smokers and 78 non-smokers in the village of Monmata Lhoong District. Results: Analysis was performed using the Mann-Whitney test. The result showed a significant difference between tooth loss in smokers and non-smokers $(p<0.05)$. Conclusion: There is a significant difference between the number of tooth loss in smokers compared to the number of tooth loss in non-smokers. The mean value of smokers is higher than the mean value of non smokers.
\end{abstract}

Keywords: Tooth loss, cigarette, periodontal disease, nicotine, smoker, non-smoker.

p-ISSN:1979-0201; e-ISSN: 2549-6212; Available from: http://jurnal.unpad.ac.id/pid/article/view/19342

DOI: 10.24198/pid.vol30no3.19342

Submission: Apr 29, 2018; Reviewed: Jun 28, 2019; Accepted: Jul 29, 2019; Published online: Jul 31,2019

\section{INTRODUCTION}

Tooth loss is a condition that occurs in most of the world's population. ${ }^{1}$ The effects of tooth loss are aesthetic disturbance, changes in the oral mucosa, loss of dental function, loss of tooth contact and impaired masticatory function. ${ }^{2}$ The most common cause of tooth loss are caries and periodontal disease. Periodontal disease can usually worsen by bad habits such as smoking. ${ }^{3}$
Smoking usually accelerates the course of periodontal disease such as fibroblast dysfunction and decreased microcirculatory function in periodontal tissues. Periodontal tissue damage in smokers may be affected by impaired ability to repair damaged tissue. ${ }^{3}$ In smokers it shows the excess of inflammatory molecules and suppresses anti-inflammatory molecules thus causing inflammatory damage from connective tissue and alveolar bone. ${ }^{4}$ 
The components of smoke of cigarette consist by gases and particles, including carbon monoxide, hydrogen cyanide, nitrogen oxides, formaldehyde, acrolein, benzene, nitrosamine, phenol, polyromatic hydrocarbons, carbarzoles, cresols, benzopiren, cadmium, ammonia, methane, tar and nicotine. ${ }^{5}$ Nicotine can reduce bone density and bone mineral content by increasing the secretion of bone-resorbing factors or decreased absorption of calcium through the intestine. ${ }^{6}$ The effects of some of the chemicals contained in smoke of cigarette in the immune system and repair of tissues related to periodontal tissue destruction. ${ }^{3}$ The research conducted by Mai et al showed that the chemicals of cigarette support the formation of plaque formed from anaerobic bacteria which can alter the oral microflora and decrease the antioxidant ability of saliva. ${ }^{6}$

Research conducted in developed countries such as the United States, Japan, Germany and Italy shows that there is a significant association between smoking and tooth loss. ${ }^{4}$ Jaleel et $\mathrm{al}^{7}$ conducted a study in 2014 at urban India, which compared the tooth loss of smokers and nonsmokers which showed significant results and found an association between the average number of tooth loss in smokers and non-smokers. ${ }^{7}$ However, research conducted by Hanioka et $\mathrm{al}^{8}$ in 2007 at the city of Kadapa-South India said that no relationship was found between smoking and tooth loss. ${ }^{8}$

Smoking habbit usually difficult to stop. The Most smokers in young age (14-17 years old) only follow the trend without knowing what is the impacts of the smoking and eventually become a habit until adulthood. ${ }^{9}$ Like the people in the village of Monmata Lhoong - Aceh Besar, one area that is close to the capital of Banda Aceh, with a distance of Banda Aceh - Lhoong $54 \mathrm{~km}$. Based on the above description, the authors were interested in conducting research in the village of Monmata because although the area fairly close to the capital but Lhoong until now is still considered as remote area by the government of Aceh Besar. Based on research in high school students in Banda Aceh City and Aceh Besar district, it showed the students of smokers reached $46 \%$, among men $65 \%$, women $2 \%$ while active smokers reached $23.7 \%$. In Lhoong Monmata village, from the results of observations and interviews, information was obtained that most of teenagers were dropped out of school, therefore many of them started smoking cigarettes when they were adolescence. The purpose of this study was to determine the difference between the number of tooth loss in smokers and non smokers in the village of Monmata Lhoong Aceh Besar District, Indonesia.

\section{METHODS}

The type of this research was analytical study. The design used was cross sectional study. The study was conducted in March 2016 that started from March 24, 2016 to March 27, 2016 in Monmata Lhoong Village, Aceh Besar District. The population of the research is the entire community of Monmata Village. Subjects in this study were Monmata village people aged 26-69 years and meet the inclusion criteria. The large determination of the subject is based on tables of Isaac and Michael. Determination of the number of subjects in this study based on the tables of Isaac and Michael, if the population is 366 people then the number of subjects to be studied is 155 subjects and rounded up to 156 subjects with a level of accuracy of $10 \%$. The number of subjects to be studied was 78 smokers and 78 non-smokers. The inclusion criteria: Smokers and non Smokers, willing to be the subject of research, male and female, aged 26-69 years, while exclusion criteria: smokers and non smokers who have a history of diabetes mellitus, tooth loss caused by trauma, and orthodontic treatment, experiencing stomatitis aphtous ulcer and trismus.

After approved by local Ethical Committee from the Faculty of Dentistry of Syiah Kuala University (the letter number of the Ethical Clearance: $027 / \mathrm{KE} / \mathrm{FKG} / 2016$ ) and obtained permission from the village head of Monmata, residents were collected at the monmata village hall and then subjects selected according to the inclusion criteria, furthermore, provided information to the subject about the study. When the subjects were agreed, the subject of the study signs the informed consent. Subjects included in the inclusion criteria were clinically examined. In the clinical examination, each subject was asked to open the mouth and performed an intra oral examination to see the tooth loss using 2 mouth 
mirror. The mouth mirror was used to pull the corners of the mouth and saw how many teeth were missing, after the clinical examination, the subjects were photographed for documentation. Clinical examination results were recorded in the available form. The research data that has been collected from clinical examination then processed and analyzed using Statistical Program for Social Science (SPSS) program version 16. The data analyzed with Mann-Whitney test which conducted on two groups of data that were not related to each other.

\section{RESULTS}

This study used primary data obtained through intraoral examination and interviews in the community of Monmata Village. People who experienced tooth loss were recorded as shown in Table 1.

Table 1. Number of tooth loss in smokers and non-smokers in Monmata Lhoong Village.

\begin{tabular}{lllll}
\hline \multicolumn{5}{c}{ Number of tooth loss } \\
\hline & $\begin{array}{l}1-2 \text { teeth } \\
(\%)\end{array}$ & $\begin{array}{l}3-5 \text { teeth } \\
(\%)\end{array}$ & $\begin{array}{l}\geq 6 \text { teeth } \\
(\%)\end{array}$ & Total (\%) \\
\hline $\begin{array}{l}\text { Smokers/ } \\
\text { person }\end{array}$ & $\begin{array}{l}19(24.4) \\
\text { Non }\end{array}$ & $\begin{array}{l}50(64.1 \\
\%)\end{array}$ & $9(11.5 \%)$ & $78(100 \%)$ \\
$\begin{array}{l}\text { Nonokers/ } \\
\text { smo }\end{array}$ person & $\%(61.5$ & $\begin{array}{l}30(38.5 \\
\%)\end{array}$ & $0(0 \%)$ & $78(100 \%)$ \\
\hline
\end{tabular}

Based on Table 1, from 78 smokers, highest tooth loss was 3-5 teeth which was found in 50 people $(64.1 \%)$, while 78 non-smokers, the most dominant tooth loss was 1-2 teeth which was found in 48 people(61.5\%).

Table 2. Percentage of Monmata villagers experience tooth loss by age group

\begin{tabular}{cccc}
\hline \multicolumn{4}{c}{ Status } \\
\hline Age & Smoker & Non Smoker & Total \\
\hline $26-35$ & $21(48.8 \%)$ & $22(51.1 \%)$ & $43(100 \%)$ \\
$36-45$ & $30(47.6 \%)$ & $33(52.3 \%)$ & $63(100 \%)$ \\
$46-55$ & $17(53.1 \%)$ & $15(46.8 \%)$ & $32(100 \%)$ \\
$56-65$ & $10(55.5 \%)$ & $8(44.4 \%)$ & $18(100 \%)$ \\
\hline
\end{tabular}

Table 2 presents the percentage of tooth loss in the villagers of Monmata by age group. Smokers were most likely to have tooth loss at 56-65 years old $(55.5 \%)$ while tooth loss in the non-smokers group was found at $36-45$ years old (52.3\%).
Table 3. Causes of tooth loss in smokers and non-smokers in Monmata Village communities

\begin{tabular}{lll}
\hline & \multicolumn{2}{l}{ Cause of tooth loss } \\
\hline & Caries & Periodontal disease \\
\hline Smokers/person & $32(41 \%)$ & $46(59 \%)$ \\
Non Smokers/person & $53(68 \%)$ & $25(32 \%)$ \\
\hline
\end{tabular}

Table 3 showed the cause of tooth loss in smokers and non-smokers in the village of Monmata where smokers experience significant tooth loss (46 people) due to periodontal disease whereas in non-smokers there is more tooth loss (53 people) due to caries.

Table 4. Types of cigarettes in Monmata villagers

\begin{tabular}{|c|c|c|}
\hline & Types c & garette \\
\hline \multirow{2}{*}{ Smokers } & Filter & Kretek \\
\hline & 31 person $(40 \%)$ & 47 person $(60 \%)$ \\
\hline
\end{tabular}

Smokers in the Monmata Village Community (Table 4) consume more kretek cigarettes than filter cigarettes.

Table 5. Number of cigarettes smoked in Monmata Village

\begin{tabular}{cccc}
\hline \multicolumn{4}{c}{ Number of cigarettes/ day } \\
\hline \multirow{2}{*}{$\begin{array}{c}\text { Smokers/ } \\
\text { person }\end{array}$} & $1-4$ cigarettes & $5-14$ cigarettes & $>15$ cigarettes \\
\cline { 2 - 4 } Total & $5(6 \%)$ & $34(44 \%)$ & $39(50 \%)$ \\
\hline \multicolumn{4}{c}{78 person } \\
\hline
\end{tabular}

Based on Table 5, the smokers in Moonmata village were most dominant in the category of smoking more than 15 cigarettes per day.

Table 6. Duration of smoking amongst Monmata Village smokers

\begin{tabular}{cccc}
\hline \multicolumn{4}{c}{ Duration of Smoking } \\
\hline $\begin{array}{c}\text { Smokers } / \\
\text { person }\end{array}$ & $<10$ years & $10-20$ years & $>20$ years \\
\hline & $4(5 \%)$ & $33(42 \%)$ & $41(53 \%)$ \\
\hline Total & \multicolumn{3}{c}{78 person } \\
\hline
\end{tabular}

Table 6 shows that most smokers in the Monmata village have the smoking duration category of more than 20 years.

Table 7. Mean score of tooth loss

\begin{tabular}{cccc}
\hline Status & N & $\begin{array}{c}\text { Mean score } \\
\text { of tooth loss }\end{array}$ & P-value \\
\hline Smokers & 78 & 96.47 & 0.000 \\
Non Smokers & 78 & 60.53 & \\
\hline Total & & 156 & \\
\hline
\end{tabular}

Mann-Whitney test ( $p<0.05$ is significant) 
Table 7 shows the mean of tooth loss number, which the mean value for smokers was higher (96.47) than the mean for non-smokers (60.53). Based on Mann-Whitney test results in Table 7, it can be seen that the test results show that there is a significant difference in the number of tooth loss in smokers and non smokers $(p<0.05)$.

According to the age, most smokers found tooth loss in 56-65 years old as much as $55.5 \%$, but in non smokers the most tooth loss found in 36-45 years old (52.3\%). While based on gender, in this study, all the smokers were male and the no smokers were female. It was found that male subjects lost their teeth more than female.

\section{DISCUSSION}

Tooth loss is a condition of individual tooth fall out from the socket caused by retraction due to caries or periodontal disease, trauma and systemic disease. ${ }^{10}$ The most common cause of tooth loss are caries and periodontal disease. Periodontal disease can usually increase or become worse by bad habits such as smoking. ${ }^{3}$ Smoking is a risk factor for some diseases and shows adverse effects on periodontal health and smoking also causes decreased salivary secretion. ${ }^{11}$ Some components of the smoke of cigarette that can exacerbate periodontal disease such as nicotine and tar. ${ }^{6}$

This study concerns the difference in the number of tooth loss in smokers and non smokers in the village of Monmata Lhoong Sub-district, Aceh Besar District. Subjects in this study were smokers and non smokers aged 26-69 years. The subject of research conducted selected using Table Isaac and Michael and got the overall subject of research as many as 156 people, divided into 78 smokers and 78 non smokers people.

Based on Table 1 there were differences in the number of tooth loss in smokers and nonsmokers in the village of Monmata, where in the group smokers, experience tooth loss of 3-5 teeth, as much 50 people whereas in non smokers suffered a tooth loss of $1-2$ teeth ie 48 people. More tooth loss in smokers may be due to the effects of nicotine and tar. Nicotine causes a reduction in bone density and bone mineral content while tar provides a direct irritant effect on gingiva that causes gingivitis, so that both components of the smoke of cigarette can accelerate the course of periodontal disease and also increased the risk of caries.6,11 Tar and nicotine are two important chemicals contained in cigarettes, nicotine is addictive while tar is carcinogenic. ${ }^{12}$ Nicotine can also benefit to the body if it is consumed in not excessive, for example nicotine can be used to treat nervousness because it can give the sedative effect. Clinically apply nicotine as a treatment of learning and memory impairment and its underlying disorders, biologically active metabolite is more than just a biomarker of nicotine consumption and has potentially therapeutic value in the treatment of learning and memory declines. ${ }^{13}$

The percentage of tooth loss by age group in Monmata village of Kecamatan Lhoong (Table 2) showed that tooth loss in the smokers group occurred in the age range 56-65 years old where age was included in the elderly so that factors can affect tooth loss. The more increase the age, the greater the periodontal tissue damage that occurs when treatment is not conduct. Increased bone loss from bone mineral loss is exacerbated by bad habits such as smoking that can cause tooth loss. ${ }^{14}$

Tooth loss in smokers in the village of Monmata (Table 3 ) is largely due to periodontal disease. Tooth loss can be caused by caries and periodontal disease. Smoking is one of several risk factors for periodontal disease lead to speed up the course of periodontal disease through chemicals in the smoke of cigarette such as tar and nicotine that are capable of supporting the formation of plaque formed from anaerobic bacteria. Components of the smoke of cigarette can stimulate free radicals, generated by the host during the immune response process against bacterial stimulation which eventually leads to periodontal tissue damage and then increases a person's susceptibility to tooth loss due to periodontal disease. ${ }^{6}$ In smokers there is a decrease of salivary $\mathrm{pH}$ which result in high amounts of bacteria Lactobacilli and Streptococcus mutans that may cause increased susceptibility to caries, whereas tooth loss in nonsmokers is due to caries. ${ }^{6}$

In addition, more tooth loss in smokers may be caused by the type of cigarettes consumed in smokers in the village of Monmata. Subjects in this study consume a lot of kretek cigarettes (Table 4). Kretek cigarettes have a very high nicotine content compared with filter cigarettes. ${ }^{15}$ Nicotine is a major component of the smoke of cigarette that 
can weaken the host against bacterial invasion caused by plaque. Nicotine also affects blood flow in the gingiva, cytokine production, neutrophils and other immune cell functions. ${ }^{16}$

Smokers in the village of Monmata smoked $>15$ cigarettes a day (Table 5). This is consistent with the results of Ludwick and Massler's study of smoking $>15$ cigarettes a day with significant tooth loss. The more cigarettes consumed in the day the higher the risk of tooth loss in smokers where there is an increase in tooth surface damage then trigger the tooth loss. This is related to tooth loss in smokers in the community of Monmata Village. Smokers who consumed cigarettes for 10 years significantly experience changed in periodontal bone. Jansson and Lavstedt ${ }^{17}$ examined smokers who consumed $>20$ years of cigarettes and showed an association of increased bone loss and significant periodontal attachment loss as longer cigarette consumption worsened an increased attachment loss in smokers. ${ }^{17}$ Many Monmata Villagers consume cigarettes $>20$ years (Table 6), thus many of the smokers who experience tooth loss due to periodontal disease.

The results of the Mann-Whitney test showed a significant difference between the number of tooth loss in smokers and non-smokers, significant tooth loss in smokers compared with tooth loss in non-smokers (Table 7). This is in accordance with a study conducted by Hanioka et al. ${ }^{4}$ showing that there is a significant association between smoking and tooth loss due to components of the smoke of cigarette associated with tooth loss where there is damage to the dental support tissues. ${ }^{4}$

Limitations of this study were the subjects smokers of all male sex while non smoker subjects are all female sex. In women there are factors that affect tooth loss that is menopause. Menopause women have a greater risk of osteoporosis than men. This occurs because of the decrease in estrogen hormone resulting in increased bone resorption. The estrogen hormone in women serves to protect bone from loss of bone mass. ${ }^{18}$ This study also did not evaluate plaque indices nor tooth brushing habits or frequency.

\section{CONCLUSION}

There is a significant difference between the number of tooth loss in smokers compared to the number of tooth loss in non-smokers. The mean value of smokers is higher than the mean value of non smokers.

\section{REFERENCES}

1. Penchas J. Dental Implants: Made Simple. eBook format by eBookit.com; 2011. p. 7.

2. Carr, Alan B, Brow, David T. Mc Cracken's Removable Partial Prosthodontics. 12th ed. St louis: Elsevier Mosby; 2011. p.5, 20.

3. Ojima M, Hanioka T. Destructive effects of smoking on molecular and genetic factors of periodontal disease. Tob Induc Dis. 2010; 8(4): 1-8.

4. Hanioka T, Ojima M, Tanaka K, Matsuo K, Sato F, Tanaka H. Causal assessment of smoking and tooth loss: A systematic review of observational studies. BMC Public Health. 2011;11(221):1-1

5. Rodgman A, Perfetti TA. The Chemical Components of Tobacco and Tobacco Smoke. 2nd ed. CRC Press; 2013. p. 37.

6. Mai X, Wende JW, Kathleen Ms, Lamonte JM, Chen $C$, Tezal M, et al. Associations between smoking and tooth loss according to reason for tooth loss: The OsteoPerio Study. J Am Dent Assoc. 2013;144(3):252-65.

7. Jaleel BF, Nagarajappa R, Mohapatra AK, Ramesh G. Risk Indicators Associated With Tooth Loss among Indian Adults. OHDM. 2014; 13(2):170-8.

8. Reddy PS, Reddy ASK, Jain AR, Pradeep R. Tooth Loss Prevalence and Risk Indicators in an Isolated Population of Kadapa- South India. American Journal of Public Health Research. 2014;2(6):221-5.

9. Ikhsan H, Arwani, Purnomo. Pengaruh Pendidikan Kesehatan Bahaya Merokok Terhadap Perilaku Mengurangi Konsumsi Rokok pada Remaja (studi kasus di Dukuh Kluweng desa Kejambon kecamatan Taman kabupaten Pemalang). J IImu Keperawatan dan Kebidanan. 2013;193):1.

10. Titjo OC, Lampus BS, Juliatri. Perilaku Masyarakat Pengguna Gigi tiruan Lepasan di Kelurahan Bahu. J e-Gigi. 2013;1(2): $1-8$. 
11. Smejkalova J. Jacob V. Hodacova L. Fiala Z. Slezak R. Vellappally S. The Influence of Smoking on Dental and Periodontal Status. Oral Health Care. 2012;249-270.

12. Kusuma DA. Yuwona SS. Wulan SN. Studi Kadar Nikotin dan Tar Sembilan Merk Rokok Kretek Filter yang Beredar di wilayah Kabupaten Nganjuk. J Tek Pert.5(3):151-5.

13. Majdi A ,Kamari Farzin, Eteghad SS, Gjedde A. Molecular Insights Into Memory-Enhancing Metabolites of Nicotine in Brain: A Systematic Review. Frontiers in Neuroscience. 2019;12: 1-11.

14. Ratmini NK. Arifin. Hubungan Kesehatan Mulut dengan Kualitas Hidup Lansia. Jurnal IImu Gizi. 2011;2(2):139-47.
15. Noerjanto B, Wahyuni RO. Alveolar Bone Destruction in Kretek Cigarrete Smoker with Nicotine Level of 2,7 mg and 2,2 mg Trough Radiographic. Prima Fiducia Andini. 2012; 3(1).

16. Malhotra R, Kapoor A, Grover V, Kaushal S. Nicotine and Periodontal Tissue. J Indian Soc Periodontol. 2010; 14(1):72-99.

17. Shaju JP. Smoking as a Risk Factor for Periodontitis: A Literature Review. odonto cienc. 2010;25(4):406-11.

18. Harvey N. Cooper C. Pencegahan Penyakit : Osteoporosis dan Fraktur Panggul dalam Gizi Kesehatan Masyarakat. Buku Kedokteran EGC : Jakarta; 2009. p. 21. 